\title{
What Is a Supranational Constitution? An Essay in International Relations Theory
}

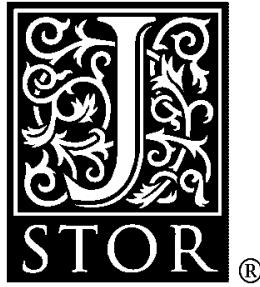

\author{
Alec Stone \\ The Review of Politics, Vol. 56, No. 3, Special Issue on Public Law. (Summer, 1994), pp. \\ 441-474.
}

Stable URL:

http://links.jstor.org/sici?sici=0034-6705\%28199422\%2956\%3A3\%3C441\%3AWIASCA\%3E2.0.CO\%3B2-Y

The Review of Politics is currently published by University of Notre Dame du lac on behalf of Review of Politics.

Your use of the JSTOR archive indicates your acceptance of JSTOR's Terms and Conditions of Use, available at http://www.jstor.org/about/terms.html. JSTOR's Terms and Conditions of Use provides, in part, that unless you have obtained prior permission, you may not download an entire issue of a journal or multiple copies of articles, and you may use content in the JSTOR archive only for your personal, non-commercial use.

Please contact the publisher regarding any further use of this work. Publisher contact information may be obtained at http://www.jstor.org/journals/notredamepolitics.html.

Each copy of any part of a JSTOR transmission must contain the same copyright notice that appears on the screen or printed page of such transmission.

The JSTOR Archive is a trusted digital repository providing for long-term preservation and access to leading academic journals and scholarly literature from around the world. The Archive is supported by libraries, scholarly societies, publishers, and foundations. It is an initiative of JSTOR, a not-for-profit organization with a mission to help the scholarly community take advantage of advances in technology. For more information regarding JSTOR, please contact support@jstor.org. 


\title{
What Is a Supranational Constitution? An Essay in International Relations Theory
}

\begin{abstract}
Alec Stone
Under the banner of "regime theory," the study of international relations has experienced a massive if largely unacknowledged return to law, the study of the nature, scope, and relevance of norms international politics. Regime is shorthand for forms of institutionalized cooperation in the international system. The article provides one way to assess this movement. In part I, I develop an abstract conception of constitutions as bodies of metanorms, those higher order norms that govern how lower order norms are to be produced, applied, and interpreted. I then examine the extent to which international relations theory is equipped to recognize that some international regimes are constitutional in form (part II). In part III, I propose a means of situating all regime forms, from the most primitive to the full blown constitutional, along a continuum. The central claim is that the distinction made between international and domestic society, for the most part a matter of dogma in mainstream theory, is relative not absolute.
\end{abstract}

The substitution of . . a an international organization for an international balancer is, in a sense, merely a specific instance of the general feature of all constitutions; a constitution seeks to balance various governmental powers and organizes a balance of interests ... in the community.

-C.J. Friedrich ${ }^{1}$

\section{Introduction}

The study of law is largely a science of norms; the study of politics is largely a science of how power is used. The distinction is a crude one, but perhaps no more crude than cross-disciplinary distinctions between "things legal" and "things political." Of course, the most traditional academic lawyer notices that legal norms are produced, manipulated, and find social agency in a world of politics; and hardheaded political realists recognize that

1. Carl J. Friedrich, Constitutional Government and Democracy (Boston: Ginn, 1950), p. 86. 
raw power politics are sometimes full of law. Still, lawyers labor, almost instinctively, to insulate their work from politics-because the political world has vast potential to disturb their carefully constructed hierarchies of norms and values. Political scientists tend to discount law as either creative force or negative constraint on political processes and outcomes. Law is instead pushed into the background, an (unproblematic) institutional control providing ceteris paribus stability for the examination of dynamic political processes; or law is itself the (conveniently) codified outcome of these processes. This dual myopia is far less acute in the study of constitutions, precisely because constitutional law is consensually understood, within and across disciplines, to be political law. The empirical and normative concerns of lawyers and political scientists unavoidably overlap in the study of constitutional law, and this overlap has led to a long and profitable exchange about the intimate connections of law to politics. The myopia approaches blindness in the study of international relations.

What is a supranational constitution? I began asking this question after having made three observations. First, I noticed that the study of international relations was in the throes of an unacknowledged, perhaps even unconscious, return to law-the study of the nature, scope, and relevance of norms in international politics. This has occurred under the banner of "international regimes," shorthand for forms of institutionalized cooperation among sovereign states. Second, I noticed that the "international regime" of the international relations theorist was indistinguishable, conceptually and analytically, from what I took to be a "constitution." Third, I noticed that public lawyers and judges had-all but unanimously-proclaimed the European Union (EU) a constitutional polity. ${ }^{2}$ EU lawyers now not only study EU law as constitutional law, but are busy working to construct that law. Examining more systematically these interconnections, it seemed, might yield at least a primitive response to the question-what is a supranational constitution? This article proposes such a response.

2. Federico G. Mancini, "The Making of a Constitution for Europe" in The New European Community, ed. R. Keohane and S. Hoffmann (Boulder: West View, 1991), pp. 177-94; Eric Stein, "Lawyers, Judges, and the Making of a Transnational Constitution," American Journal of International Law 75 (1981): 1-27; Joseph Weiler, "The Transformation of Europe." Yale Law Journal 100 (1991): 2403-83. 
The article is divided into three parts. In part 1,1 discuss the notion of constitution developed here, a body of metanorms governing how lower-order norms are produced, applied, and interpreted. In part 2, I survey how different strains of international relations theory might answer my question. Because international cooperation is generally viewed as inherently problematic in international politics, and because one can hardly imagine a more intricate form of cooperation than that which has been constitutionalized, international relations theory is not well disposed to ask let alone answer my question. In part 3, I focus on the nature and functioning of norms in the formation and maintenance of international regimes. I generate a continuum of regimes capable of situating all forms of institutionalized cooperative behavior, including the supranational constitutional.

\section{Norms, Laws, Constitutions}

"A norm," Axelrod tells us, "exists in a given social setting to the extent that individuals usually act in a certain way and are often punished when seen not to be acting in this way." ${ }^{\prime \prime}$ The social logic of norms is straightforward. Norms resolve collective action problems, hence their social legitimacy. Indeed, most social settings are hardly anything but a set of particular normative resolutions to a cluster of particular collective action problems.

The microfoundation of norms-their origin and longevity -is problematic, and remains a matter of controversy. ${ }^{4}$ This is because the process by which a norm is established, or maintained, is itself a potentially irresoluble collective action problem. At the level of any individual actor, we understand a norm to be a regularized constraint on behavior in the service of what I will call "the social interest." The critical test of a norm's robustness, or legitimacy, occurs when the social interest comes into evident conflict with the self-interest, or interest-driven objectives, of any given individual (or group among groups). In such a case, an individual may well choose to behave in contravention of a norm, especially if the probable outcome of not doing so is to leave that individual

3. Robert Axelrod, "An Evolutionary Approach to Norms," American Political Science Review 80 (1986): 1095-1111.

4. Taken up again in part 2. 
worse off. As Axelrod's definition implies, social norms are moreor-less clear, more-or-less "obeyed," and contraventions are moreor-less punished. To the extent that a social norm is less clear, less respected, and less punished relative to others, that norm-and the social interest which it serves-can be said to be less legitimate.

Legal norms are distinguished from other social norms not in kind, but by their higher degree of clarity. Clarity facilitates the diffusion of norms, by reducing uncertainty about their content, and by lowering the costs of monitoring compliance and punishing contraventions. Law is the fetishization of normative clarity. Law formalizes, by making explicit, the rights and obligations of individuals - or groups or sovereign states - to act in a particular way, "in a given social setting." Put differently, legal norms are a highly transparent expression of the superiority of the social interest relative to self-interest in any social transaction. They codify just how duty preempts choice. Where such an interest has been established, the contravention of a norm constitutes an injury against the group as a whole. Norms thus establish reciprocal relationships among individuals at the group level. Because of this, legal norms have the capacity to constitute or otherwise define a political community, so much so that the legitimacy of such norms can hardly be distinguished from political legitimacy. ${ }^{5}$

\section{COnSTITUTIOns as MeTANoRms}

For my purposes, ${ }^{6}$ a constitution denotes a body of metanorms, rules that specify how legal norms are to be produced, applied, and interpreted. Metanorms are thus not only higher-order but prior, organic norms - they constitute a polity. Metanorms enhance the legitimacy of legal norms (and therefore social legitimacy) not unlike the way higher degrees of clarity enhance the legitimacy of norms generally: metanorms make more transparent the processes by which legal norms are produced, compliance is monitored, and infractions punished. Thus, metanorms fix the rules of the game, as a means of investing lower-order norms with authority (legitimacy). To the extent that these rules are expected to be longlived, or quasi-permanent, the establishment of metanorms is an institutionalization of the social interest.

5. The quasi-identity is familiar to students of comparative politics.

6. I am consciously seeking to distill an essentialist if abstract conception of constitution here and in the typology below. 
In the real world, metanorms function to establish highly institutionalized social settings. In the real world, to take just one example, constitutions establish formal state institutions. ${ }^{7}$ Such institutions exist, above all else, to assert or ensure, in an ongoing manner, the superiority of the social interest over contrary self or group interests-as when a legislature passes a statute, an agency applies an administrative rule, a policeman makes an arrest, or a court settles a dispute.

Accepting these commonalties, constitutions differ substantially. I will focus here only on differences in how metanorms constrain the production of lower-order norms. Once simplified, these differences can be (crudely) organized in a typology. This typology includes the following three ideal types.

${ }^{\circ}$ Type 1: the absolutist constitution. In this constitutional form, the authority to produce both meta- and lower-order norms is centralized and absolute. The controlling metanorm is the fact of absolutism: as long as the sovereign retains "above the law" status, other metanorms may be changed without altering regime type. In such a system, lower-order norms are either commands of a (coherent) sovereign, or are the byproducts of such commands. In type 1 systems, metanorms possess no meaningful autonomy: metanorms reflect the interests, rather than restrict the discretionary power, of the sovereign; norms are legitimized by political power, not vice-versa. The form is that of Hobbesians, of pre-physiocratic, Continental state theory, and of the more banal authoritarianism of the twentieth century.

'Type 2: the legitimizing constitution. In this form, metanorms are quasi-permanent and relatively autonomous (metanorms themselves control how the rules of the game are to be revised). Such systems are based on common tenets of rule of law, or Rechtsstaat, ideology: lower-order norms, so long as they are produced according to procedures laid down by metanorms, bind the entire polity. In liberal democracies, type 2 metanorms

7. Metanorms may be present in, and constitutive of, a wide range of "constitutionalized" social settings, such as universities, trade unions, major league baseball, corporations. 
do two things: they distribute capacities and functions among state institutions; and they establish a stable set of electoral and institutional rules. Elections legitimize legislative authority, and legislative majorities legitimize statutory authority. Once promulgated, statutes are sovereign commands (until abrogated by subsequent commands), binding administrators and judges. The British parliamentary system and the French third and fourth republics are examples.

- Type 3: higher law constitutionalism. In both type 2 and 3 forms, organic metanorms legitimize government authority by establishing institutions and rules as to their appropriate functioning, and by linking institutions to society (e.g., via elections). In a type 3 system a layer of normative constraints, on the content of lower-order norms, is added. These substantive constraints-usually expressed in charters of rights-give to nonstate actors enforceable claims against the state. These claims are arguments that state acts are invalid (illegitimate) because they violate constitutional rights. In such polities, the production of lower-order norms is relatively decentralized and more participatory. The legislative process, for example, does not end upon promulgation of legislation, but is lengthened by judicial politics, and opened up to include litigants and judges. Examples of type 3 polities are Canada, the United States, and the Federal Republic of Germany.

A critical test of a metanorm's relative autonomy is the extent to which it is capable of constraining the behavior of those in power. A set of metanorms devoid of autonomy can hardly be considered normative at all, and for this reason many will refuse to recognize type 1 constitutionalism as constitutionalism at all. ${ }^{8}$ In any case, the absence of meaningful autonomy probably reduces longevity; intraregime succession is rarely smooth, and often fatal. On the

8. Friedrich notes that "the word [constitution] has for modern political science a very distinct meaning, namely, as the process by which government is effectively restrained," Friedrich, Constitutional Government and Democracy, p. 123. Lenaerts defines constitutionalism as "limited government operating under the rule of law" (Koen Lenaerts, "Constitutionalism and the Many Faces of Federalism," American Journal of Comparative Law 38 [1990]: 205). 
other hand, we know that all norms function to the benefit of some, mostly the powerful, and to the detriment of others, which partly accounts for their durability. Type 2 polities are relatively more durable because they legitimize social competition, empowering whomever wins with the right to rule. Any alternance or Machtwechsel-the transfer from one group to another-in turn may be said to legitimize the metanorms. The metanorms demonstrate, however imperfectly realized, that a loser today may win tomorrow. In type 3 systems, the relative autonomy of metanorms is at its greatest: rights claims mitigate what is absolute in type 2 forms, that is, the sovereign status of statute. Such claims are subject to formal adjudication, in the courts, administrative agencies, or in specialized constitutional organs. In such polities, metanorms legitimize ongoing processes of interpretation, of all legal norms, including the metanorms.

\section{INTERNATIONAL REGIMES AND CONSTITUTIONALISM}

An international regime, according to the now consensus definition, is a body of "implicit or explicit principles, norms, rules, and decision-making procedures around which actors' expectations converge in a given area of international relations." 9 One finds, in the burgeoning literature on regimes, a great deal of disagreement as to the relative status of these different "implicit and explicit" elements. ${ }^{10}$ In Krasner's own words, principles are "beliefs of fact, causation, and rectitude"; norms are "standards of behavior defined in terms of rights and obligations"; and decisionmaking procedures are the "prevailing practices for making and implementing collective choices."11 From the perspective developed here, norms may be either lower order rules-like legislation-or may be metanorms. Decision-making procedures (and perhaps even principles) are indistinguishable from metanorms, to the extent that they establish a common purpose,

9. Stephen D. Krasner, "Structural Causes and Regime Consequences: Regimes as Intervening Variables," in International Regimes, ed. S. Krasner (Ithaca, NY: Cornell University Press, 1983), pp. 1-22.

10. Stephen Haggard and Beth A. Simmons, "Theories of International Regimes," International Organization 41 (1987): 491-517; Friedrich V. Kratochwil, Rules, Norms, and Decisions (Cambridge, UK: Cambridge University Press, 1989).

11. Krasner, "Structural Causes and Regime Consequences," p. 2. 
determine the status of the players, and fix the rules of the game. "Rules," for Krasner, are "specific prescriptions or proscriptions for action"; rules then are simply lower-order norms binding on the community as a whole. Although most international regimes are probably not constitutional, there is nothing inherent in the notion of an international regime which can exclude constitutionalization. Regimes are simply a highly demanding form of community based on norms, and constitutional regimes are a highly demanding form of regime.

A survey of the regime literature as a whole would be more tedious than illuminating, but a few remarks are warranted at this point. Some scholars have sought to include tacit forms of cooperation as regimes. In such a formulation, almost any persistent form of state interaction constitutes a regime. Thus, the management of nineteenth-century colonialism by Western powers is a regime, however informal the norms embodied. ${ }^{12}$ The dominant focus, however, has been on regimes created by treaty law. I surveyed all articles written on specifically identified regimes published in International Organization and World Politics during the decade following the appearance of the Krasner volume. None focused on informal regimes; each was an analysis of regimes created by one or more international treaties. Nevertheless, as we have seen, the notion of regime is inherently vague, and thus may denote an extraordinary range of behavioral patterns. In part III, I propose a norm-based means of discriminating among regime types (part III).

\section{International Relations Theory and Supranational Constitutionalism}

This part has two interrelated purposes. The first is to survey the major schools of thought in international relations theory with respect to the prospects for norm-driven cooperation to be institutionalized in constitutional forms. The second is to (very briefly) show how theoretical differences among these schools result in very different assessments of interstate cooperation, taking the EU as an example. The argument that the EU regime has been "constitutionalized" will not be taken up directly until part III.

12. Donald J. Puchala and Raymond F. Hopkins, "International Regimes: Lessons from Inductive Analysis," in International Regimes, ed. Krasner, pp. 61-91. 


\section{NeOREALISM}

The field of international relations was fundamentally recast by the appearance of Waltz's Theory of International Politics. ${ }^{13}$ The book synthesized and made more coherent what Waltz took to be the crucial tenets of a realist theory of international politics. The book not only established a "neorealist" agenda, but its central arguments came to constitute, for adherents and opponents alike, a kind of doctrinal expression of "mainstream" international relations theory. Alternative theoretical perspectives came to be defined in terms of their differences with "neorealism."14 In the field of international relations, the 1980s was the decade of Kenneth Waltz.

Stated in the language of this article, neorealism is a theory of why, in "international political" society, the establishment of stable norms is either unlikely or impossible, why formal institutions do not develop meaningful autonomy, and therefore why a constitutional international regime is unimaginable. Neorealism is above all else an elaboration of how a particular structureanarchy-constrains development of international society, accounting "for the striking sameness in the quality of international life through the millennia."15 The meaning of anarchy is clarified by way of two analogies. The first, the domestic analogy, is used to define anarchy negatively. For Waltz, the structure of domestic politics is "centralized and hierarchic":

the parts of domestic political systems stand in relations of superand subordination. Some are entitled to command; others are required to obey.

This is very much the language of constitutional law, that is, centralized-hierarchical structures, that is, states, are those produced by metanorms. For Waltz, constitutional structures: (1) establish hierarchical relations among formal institutions; (2) "specify the functions of formally differentiated units," that is, the tasks each institution is to perform; and (3) distribute "capabilities

13. Kenneth N. Waltz, Theory of International Politics (New York: McGraw Hill, 1979).

14. Robert O. Keohane, ed., Neorealism and Its Critics (New York: Columbia University Press, 1986).

15. Waltz, Theory of International Politics, p. 66. 
across these units," that is, the power to perform these tasks. In contrast, international systems are "decentralized and anarchic." The "parts" of this system-states and states alone-are "like units," undifferentiated by function. ${ }^{16}$ Moreover, they do not stand in any fixed, formal, hierarchical relation with one another. ${ }^{17}$ On the contrary, the metanorm of the international system is that of state sovereignty, a formal denial of hierarchy among the structural units.

These two components-anarchy as structure, and states as constituent like units-are not allowed to vary. We might, for example, wish to stretch a continuum between the poles of anarchy and hierarchy, a continuum representing trade-offs between the two, and on which we might place a variety of real world communities. We might wish to do so, in particular, if we were seeking to answer the question, "what is a constitution?" But to do so would be to sacrifice "clarity and economy of concepts." 18 We might wish to distinguish between types of states, noticing and investigating the influence of a given state's "ideology, form of government, peacefulness, bellicosity, or whatever."19 But to do so would be to confuse unit-level with systemic effects, abandoning the study of international relations-the implications of anarchy on international politics-for the study of comparative politics or comparative foreign policy. ${ }^{20}$ The only structural or "system-wide concept" permitted to vary by Waltz is "the distribution of capabilities across units." Thus, states are not differentiated by form or function, but only by how much power they possess relative to others.

A second analogy is used to show how anarchy inhibits cooperation among states while nevertheless producing order. For Waltz, the state system is partly analogous to another anarchic, order-producing, structure-the unregulated free market of microeconomic theory. Like a market, international structures are not consciously made, but are instead "spontaneously formed by

16. Since "each state duplicates the activities of other states," (ibid., p. 95).

17. Ibid., chap. 5 .

18. Ibid., pp. 114-15.

19. In fact, Waltz does just this in order to demonstrate how structure matters in his comparison of the impact on metanorms on political outcomes in Great Britain and the United States, (ibid., pp. 81-88).

20. Ibid., pp. 72, 98, 122. 
the self-interested acts and interactions of individual units. ${ }^{21}$ States are like firms, but with armies; they compete for power in a world of scarcity, in much the same way as firms compete for greater market shares; and, just as firms do, they tend to mimic the successful strategies of their competitors (what Waltz calls "socialization"). The assumption of rationality and coherence is therefore central. Order is demonstrated in part by the very existence of ongoing competition (a permanently constituted, iterated game is a form of order). Perhaps most important, states cannot assume that they will survive any more than a business can assume that it will never go bankrupt. Indeed, following Hobbes, the threat of violence and war is an omnipresent fact of anarchy: "among states, the state of nature is the state of war."22 As long as this is so, states-as a result of competition and socialization-will tend to select those courses of action which guarantee their survival.

Perhaps the central tenet of neorealism is that, in a self-help system like anarchy, where survival is not assured, states face formidable, often insuperable obstacles to institutionalizing cooperation. Although functional differentiation in hierarchy makes cooperation and interdependence safe and even somewhat necessary, in anarchy such differentiation expresses relative vulnerability. The weak may not be able to resist dependence on, or interdependence with, the strong, but a privilege of power for dominant states is the capacity to maintain maximal autonomy. ${ }^{23}$

Among neorealists, if not Waltz, the language of collective action and game theory is the most popular way of expressing the problem, ${ }^{24}$ not least because much of game theory, like neorealism, assumes the absence of both hierarchy and functional differentiation among coherent, utility-maximizing units, or players. States are caught in a classic Prisoner's Dilemma (PD), that is, even when two or more states know that they share common goals and know that cooperation would leave them each better

21. Ibid., p. 89.

22. Ibid., p. 102.

23. Ibid., pp. 106-107.

24. Robert Axelrod, The Evolution of Cooperation (New York: Basic Books, 1984); Robert Axelrod and Robert O. Keohane, "Achieving Cooperation Under Anarchy: Strategies and Institutions," World Politics 38 (1985): 226-54; Joseph M. Grieco, "Anarchy and the Limits of Cooperation: A Realist Critique of the Newest Liberal Institutionalism," International Organization 42 (1988): 485-507. 
off, the incentives are such that "successful cheating" is preferred to cooperation, and defection is preferred to being victimized. "In these circumstances," writes Grieco, "and in the absence of centralized authority or some other countervailing force to bind states to their promises, each [state] defects regardless of what it expects the other to do." ${ }^{25}$ We know that incentives to cooperate can be bolstered by repetitive play, by signalling, by establishing a reputation for cooperative behavior (as in tit-for-tat), and by introducing punishments for defection. ${ }^{26}$ Neorealists view each of these antidotes as either too weak or too costly for states to rely on in decentralized society. But the crucial barrier to cooperation, operating even when incentives to cooperate are stronger than disincentives, remains exogenous to the game: the survival imperative:

Driven by an interest in survival, states are acutely sensitive to any erosion in their relative capabilities, which are the ultimate basis for their security and independence in an anarchical, self-help international context. ... [T] The major goal of states in any relationship is not to attain the highest possible individual gain or payoff. Instead, the fundamental goal is to prevent others from achieving advances in their relative capabilities. ${ }^{27}$

States have no choice, since in international politics relative capabilities can be used to obtain absolute advantage.

Nonetheless, anarchy does favor the emergence of forms of systemic order based on aggregations of state power. Although the mechanisms are complex, when viewed systemically and historically, one notices that balancing behavior-the formation, maintenance, and dissolution of alliances-is a universal response by states to the problem of survival within anarchy. One also notices that such balancing behavior is intimately related (and a response to) the underlying, asymmetrical distribution of power across states. The actions of dominant states, and the interactions of dominant states with each other, establish the character and political dynamics of any given system. Any given system endures

25. Grieco, "Anarchy and the Limits of Cooperation," p. 493.

26. Michael Hechter, Principles of Group Solidarity (Berkeley: University of California Press, 1987); Michael Taylor, Anarchy and Cooperation (New York: John Wiley and Sons, 1976).

27. Grieco, "Anarchy and the Limits of Cooperation," p. 498 (emphasis in original). 
only so long as this character, or equilibrium, is maintained. When the underlying distribution of power is altered, a great deal of stress is placed on the system, and systemic war is the likely result; war brings about or ratifies systemic change, creating the conditions for new equilibria to emerge. ${ }^{28}$

Can systemic order or equilibria be viewed as institutionalized order? The answer appears to be "yes," but this yes is relativized. Institutions, whether behavioral (persistent patterns of interaction) or concrete (formal organizations), are created, maintained, and act only to the extent that they reflect the interests of the most powerful states. Waltz writes:

Whatever elements of authority emerge internationally are barely once removed from the capability that provides the foundation for the appearance of those elements. Authority quickly reduces to a particular expression of capability. ${ }^{29}$

Institutionalization results primarily from the fact that balancing behavior accentuates the capabilities of dominant states. What is being "institutionalized," that is, made persistent, is not normative authority generally, but the social interest defined as a balance or imposition of power, produced by competition and reinforced by socialization.

Finally, these more-or-less institutionalized orders within anarchy can be analyzed as discrete "systems" or worlds. What distinguishes one world from another is the underlying distribution of power expressed in terms of the number of dominant states. These states, when not at war with each other, are busy balancing or otherwise organizing alliance structures into "poles," institutionalized aggregations of power. Thus we can speak of a great power multipolar world or a superpower bipolar one. One of Waltz's most influential arguments has been the notion that bipolarity is more "stable" (more capable of preserving equilibrium) than is multipolarity, principally because in the latter there is for each dominant state greater uncertainty about the status of other dominant states as rivals or allies. The uncertainty of the balancing process within multipolarity increases security concerns,

28. Robert Gilpin, War and Change in International Politics (New York: Cambridge University Press, 1981).

29. Waltz, Theory of International Politics, p. 88. 
and discounts incentives to cooperate. ${ }^{30}$ Zero-sum conditions are always maintained between dominant powers-defining their existential situation-but such conditions are relaxed for weak states within alliances. Even in interactions between these weak states, however, the obsession with relative capabilities is necessary and therefore permanent.

To summarize, the neorealist view of the international political system reserves no important place for the notion of metanorms, autonomous institutions, or independently viable norms of behavior. This is in part the consequence of a rigid, formalistic distinction between domestic hierarchy and international anarchy. It is also in part, the consequence of assuming that the meaning of anarchy is the same at all times, for all states. Anarchy imposes strict limits on cooperation, that is, on the kinds of collective action problems which can be resolved. Cooperation among states does occur, but only to the extent that failure to cooperate threatens survival. Norms and institutions may emerge to facilitate that cooperation, but they cannot develop meaningful autonomy.

\section{Hegemony and the Provision of Regimes}

The theory of hegemonic stability constitutes an attempt to explain what would otherwise be anomalous: the popularity and importance of international regimes in world politics. The theory builds on the neorealist presumption that cooperation in anarchy is inherently problematic. The theory of hegemonic stability seeks to account for dynamics of creation, maintenance, and decline of institutionalized cooperation. Regimes are rooted in the soil of hegemony, a radically asymmetrical distribution of power across states approaching, at least in large parts of the globe, quasicentralization. The theory is largely derived from one experience, that of U.S. hegemony after World War II. ${ }^{31}$ Stated simply, a dominant state may choose to "supply" a regime, that is, seek to institutionalize cooperation, "when it is sufficiently large relative

30. Ibid., pp. 161-76.

31. Those who have focused on free trade as the paradigmatic example of a collective good regime, have also examined the near-hegemony of Great Britain, from the latter half of the nineteenth century to World War II. For a review of this literature, see Robert Gilpin, The Political Economy of International Relations (Princeton: Princeton University Press, 1987), pp. 72-117. 
to the all others that it will capture a share of the benefit of the public good larger than the entire cost of providing it. ${ }^{\prime \prime 2}$ In terms of the PD, the hegemon functions as a kind of outside regulator of the game, willing not only to establish and enforce rules (manipulate incentives in favor of cooperation) but also to absorb the costs of defections played by the smaller states. The theory is faithful to central neorealist precepts. The fact of hegemony removes the security imperative, leaving states free to pursue absolute gains without worrying so much about relative gains.

While neorealists sharply disagree about how to define and evaluate hegemony, there appears to be consensus on at least three basic points. First, institutionalized cooperation is a reflection of a particular distribution of capabilities-hegemony. Second, the hegemon must prefer the creation of regimes over a noncooperative form of social organization, such as a coercive or extractive imperialism (say of the Soviet Union). In practice, this is taken to mean that the hegemon must be a liberal state. The theory thus diverges from the neorealism of Waltz, by admitting that a difference at the unit level can yield a crucial systemic outcome. Third, the social interest deteriorates as the hegemon declines; put differently, PD disincentives reassert themselves as the hegemon proves increasingly unable or unwilling to counter them. Thus, and this is a central prediction of the theory, contemporary regimes will unravel with ongoing American decline.

\section{Modified Structural Realism}

Modified structural realism (MSR), of which Robert Keohane's After Hegemony is the most coherent expression, ${ }^{33}$ can be partly understood as a corrective to hegemonic stability theory. MSR provides an explanation for the stubborn persistence of regimes

32. Duncan Snidal, "The Limits of Hegemonic Stability Theory," International Organization 39 (1989): 581.

33. Robert O. Keohane, After Hegemony (Princeton, NJ: Princeton University Press, 1984). I take After Hegemony to be a neorealist text for three interrelated reasons. Unlike neoliberals (see below), the After Hegemony Keohane: (1) accepts assumptions that states are "like-units" and that anarchy - in the absence of a regime - is an environment in which disincentives outweigh incentives to cooperate; (2) does not incorporate transnational society as a factor in a regime's creation, maintenance, or extension; and (3) does not show how regimes may develop semi-autonomous institutional capacity to generate political processes and outcomes. 
in the world despite the decline of American hegemony. It remains a theory tied to neorealism in that it largely accepts assumptions about anarchy, about the centrality and rationality of states, and about the link between power and outcomes. ${ }^{34}$ It contrasts with mainstream neorealism in its insistence that states have an interest to cooperate in increasing sum games; put negatively, concerns on the part of states for how relative gains will be distributed do not necessarily paralyze the establishment and maintenance of cooperative ventures. ${ }^{35}$ As we have seen, neorealists argue that, in conjunction with other factors, hegemony can remove the security imperative, permitting regimes to take root and prosper. But once created, according to MSR, regimes may outlive hegemony, due partly to inertia and sunk costs, and-more importantly-to the diffuse benefits a regime may supply to those it serves. A regime may survive the passing of hegemony if at least a core of the most powerful states believe that the benefits of maintaining it exceed the costs of dismantling it, or the costs of constructing a new regime. ${ }^{36}$

Much more important to our concerns, Keohane's MSR provides a (small) seat at the realist table for norms and institutions, and I will argue, for constitutionalism. Regimes, writes Keohane, facilitate ongoing collective action by performing three important functions. ${ }^{37}$ First, regimes enable states to collectively establish legal rights and obligations, and in doing so, establish "legitimate standards of behavior." Second, regimes lower bargaining costs: institutionalization iterates the game, lowering the cost of interaction over time and enhancing the capacities of players to link issues and make side payments. Third, regimes reduce uncertainty (information costs), by providing a forum and vocabulary for the signalling of preferences and intentions. Regimes that adequately perform these functions substantially mitigate the risks associated with cooperation in anarchy. Indeed, the better these functions are performed, the more one would

34. Robert O. Keohane, "Theory of World Politics: Structural Realism and Beyond," in Neorealism and Its Critics, pp. 193-95.

35. Many neorealists remain unconvinced, e.g., Grieco, "Anarchy and the Limits of Cooperation." Grieco views MSR, wrongly I believe, as a form of neoliberalism.

36. Keohane, After Hegemony, chaps. 5, 8, 9.

37. Ibid., chap. 6. 
expect cooperative behavior to deepen in intensity and widen in scope. There is an expansionary logic to institutionalization: as the costs of defecting are increased and the costs of cooperating are lowered, as linkages across issue areas become nested within a regime, as patterns of preferences structure the flow of side payments to those who would otherwise defect or block expansion, the parties to a regime are more likely to rely on it as an instrument of ongoing policy coordination.

The institutionalized cooperation of MSR is a primitive form of supranational constitutionalism. The functions of a regime laid out by Keohane are identical to the functions of metanorms: they both establish institutional fora and procedures for political interaction which results in the production of legal norms. These legal norms may be in the form of international agreements, but they are no less legislative for that. If supranational metanorms can not be distinguished in kind from other metanorms in this respect, anarchy remains, Keohane insists, crucial to their meaning and importance:

Sovereignty and self-help mean that the principles and rule of international regimes will necessarily be weaker than in domestic society. In a civil society, these rules specify "terms of exchange" within the framework of constitutional principles. In world politics, the principles, norms, and rules of regimes are necessarily fragile because they risk coming into conflict with the principle of sovereignty and the associated norm of self-help. They may promote cooperation, but the fundamental basis of order on which they would rest in a well-ordered society does not exist. They drift around without being tied to the solid anchor of the state. ${ }^{3 .}$

The distinction between hierarchy and anarchy reasserts itself to the extent that state-rooted enforcement mechanisms remain primitive or non-existent. ${ }^{39}$

\section{NeOREALISM AND THE EU}

Stated baldly, structural neorealists like Waltz have not been much interested in European integration processes. Such processes

38. Ibid., p. 62.

39. Why exactly regimes can never constitute solid enough "anchors" is unclear. In fact, the assertion is belied by multilateral regimes generally, and by the EC in particular (see below). 
are lower-level and epiphenomenal. The real action has occurred above Europe, at the superpower level. For Waltz the EU provides only an example of how the emergence and consolidation of bipolar structures alter the incentives to cooperation of states under a security umbrella of a superpower. His analysis (which predates the rise of hegemonic stability theory) merits quoting at length:

So long as European states were the world's great powers, unity among them could only be dreamt of. Politics among the European great powers tended toward the model of a zero-sum game. . . . When on occasion some of the great powers did move toward cooperation, they did so in order to oppose other powers more strongly. The emergence of the Russian and American superpowers created a situation that permitted wider ranging and more effective cooperation among the states of Western Europe.

Once the possibility of war among states disappears, all of them can more freely run the risk of a relative loss.... Conflicts of interest remain, but not the expectation that someone will use force to resolve them. ... Politics among European states became different in quality after World War II because the international system changed from a multipolar to a bipolar one. ${ }^{40}$

Thus, the example of the EU does not challenge neorealist theories, as some neoliberals believed, but in fact confirmed such theories.

The shift now taking place from bipolar to a multipolar world may constitute a critical challenge to neorealism. Recall that for neorealists, a multipolar world is less stable and less amenable to cooperation than is a bipolar one. One could expect, then, that the end of cold war "order" will see the unraveling of Europe. Indeed, in one of the most widely disseminated neorealist pronouncements of recent years, Mearsheimer, following Waltz, ${ }^{41}$ has argued:

Take away the... Soviet threat to Western Europe, send the American forces home, and relations among the EU states will be fundamentally altered. Without a common Soviet threat or an American nightwatchman, Western European states will do what they did for centuries before the onset of the Cold War-look upon each another with avoiding suspicion. ... Cooperation will be more difficult, ... conflict will be more likely ${ }^{42}$

40. Waltz, Theory of International Politics, pp. 70-71.

41. John Mearsheimer, "Why We Will Soon Miss the Cold War," The Atlantic Monthly (August 1990): 35-50.

42. Ibid., p. 45. 
The prediction is as clear as it is consistent with neorealist precepts: Europe "is reverting to a state system that created powerful incentives for aggression in the past"; and "we know that this multipolar Europe was plague by war from first to last." ${ }^{\prime 43}$

\section{NeOliberalism}

An approach to international relations theoretically distinct from realism-neoliberalism-has emerged. ${ }^{44}$ Neoliberalism differs from neorealism in three interrelated ways. First, states are not considered to be "like units." How they are constituted-what sort of polity they are-matters a great deal to what ultimately takes place at the systemic level. Second, there is not simply one undifferentiated "game" of international politics, but several games. The conduct of each of these games varies as a function of unit-level variation. Third, war is not the "state of nature" of international politics. Between some states-liberal statescooperation is also "natural." A state can be said to be more "liberal," the more state institutions are representative, the more civil society possesses and exercises stable political and civil rights, and the more property rights are guaranteed. Liberal states are those which can be said to be democratic and capitalist beyond some minimal threshold.

Neoliberalism has been best surveyed, taken apart, and then synthesized in a paper by Andrew Moravcsik. ${ }^{45}$ Most important, the theory problematizes what is assumed by neorealists, that international politics is conducted by rational states who come to the game with coherent preferences already fully formed.

43. Ibid., p. 36.

44. Liberal theories of international relations have traditionally been associated with "idealism," or "utopianism." Proponents of these theories saw in international law and organization the means of regulating, if not eliminating, the scourge of war, and perhaps even the creation of world government, e.g., David Mitrany, A Working Peace System (Chicago: Quadrangle Press, 1966). These liberals largely accept realist depictions of the world as accurate, but their commitments to peace and justice lead them to resist the view that anarchy is a permanent condition. Such liberals are, theoretically speaking, semirealists who believe that anarchy is evil, a point made by Moravcsik, note 45 below.

45. Andrew Moravcsik, "Liberalism and International Relations Theory," Unpublished Working Paper, Center for International Affairs, Harvard University (1992): 50 pp. 
Neorealism is a theory primarily about how states use power to bargain, threaten, and war with one another; neoliberalism is a theory about how state preferences are formed in the first place, before the bargaining begins. The overall mix of state preferences is the key variable of neoliberalism, not the distribution of capabilities: viewed as process, international politics work from the bottom up (whereas neorealist politics work from the systemlevel down).

Moravcsik identifies three "core assumptions" of liberalism, from which three variables can be derived. ${ }^{46}$ The assumptions and associated variables are as follows:

1. "The fundamental actors in world politics are individuals and privately-constituted groups with autonomous preferences";

- variable 1: "the representativeness of institutions."

2. "All governments represent some segment of domestic society, whose interests are reflected in state policy";

- variable 2: "the level of concentration of social power."

3. "The behavior of states-and hence levels of international conflict and cooperation-reflect ... patterns of conflicting or converging state preferences";

- variable 3: "the extent of transnational economic interaction."

Each of these variables constitutes part of a mechanism linking unit-level causes to system-level outcomes to the extent that each "points to [how] international conflict can result from the failure to resolve distributional conflicts between domestic social groups in a way that benefits society as a whole." Neoliberalism insists that the (dis)incentives to engage in conflict or war are not fixed by the distribution of power in the system, but in fact can be reweighted or even reversed as a function of unit-level variation. Simplifying the argument a great deal, the less representative is any government, and the more concentrated social power in the hands of a few, the more state officials can "promote aggressive policies that are beneficial to them [or the group that supports them], while compelling others to bear the costs." In liberal states, the net benefit of war (in the absence of self-defense) is unlikely to be greater than the costs of warring, costs that would be spread 
relatively more evenly throughout society. The third variable, the extent of international economic interdependence operates on both the unit and the international level. Incentives to go to war are lower where states are mutually vulnerable to disruptions of transnational economic activity. Within any state, officials are unlikely to decide to war against economic partners, since if they did they would lose the support of powerful private economic actors and leave civil society as a whole worse off. In the real world, these variables often cohere. High levels of economic interdependence, for example, occur in a zone of liberalism (Western industrial states), precisely because it is in liberal states that property rights are best protected.

Focusing on the prospects of war alone, we now see that there is not one but at least three distinct "games" being played at once. In a conflict between two liberal states which interact under conditions of high economic interdependence, both sets of state officials are similarly constrained, and war is maximally unlikely. In fact, a significant war has yet to occur between two liberal states, interdependent or not. In a conflict between nonliberal states, war is relatively much more likely, and empirically, war between nonliberal states is fairly common. In conflicts between liberal and nonliberal states, the most destructive wars of this century, war appears to be similarly unconstrained, although why this is so remains a matter of some dispute. ${ }^{47}$ Viewed through liberal lenses, then, the proposition that war constitutes "a state of nature" is simply false.

False too is the proposition that cooperation among states is inherently problematic. Within any zone of liberalism, state leaders tend to be less concerned with relative gains than they are with having civil society better off absolutely. This is in part the result of the fact that the security imperative has been removed, that is, within the zone, force has been abolished as an instrument of

47. Liberal states may sometimes have a net incentive to go to war against nonliberal states, when the zone of liberalism is perceived as threatened (selfdefense); or perhaps when force serves to impose capitalist relations on a nonliberal periphery. In either case, it is far easier for liberal leaders to mobilize civil society to war against nonliberal states than against liberal states. For versions of these and other speculations see Moravcsik, "Liberalism and International Relations Theory." 
foreign policy. It is in part due to the effects of an international division of labor, which allows liberals to invert Waltz's logic:

the trading world is not composed of states ranked in order of their power and territory, all seeking preponderance. Instead it is composed of nations differentiated in terms of function. Because nations supply different services and products, in defense as well as economics, they come to depend on each other. ${ }^{48}$

Most important, the balance of incentives in favor of cooperation is partly a byproduct of the integrative dynamics of economic interdependence. As liberal economies become increasingly linked through transnational investment and trade, so do private sectors. Interdependence creates social forces that have a stake in interdependence and that will punish illiberal policy, in future elections, and by taking business elsewhere. Put in strictly economic terms, the mobility of factors of production effectively constrains governments, reducing state autonomy over economic outcomes. Incentives to coordinate macroeconomic policy increase: in a zone of liberalism, "it becomes difficult, sometimes impossible, to achieve domestic economic targets without international cooperation to stabilize expectations about policy." 49

In Keohane's MSR, formal regimes provide the necessary catalyst for the formation and maintenance of a social interest capable of overcoming the short-term, "myopic" self-interests of states. In liberalism, the social interest can be constituted without formal institutions at all. Imagine a zone of liberalism, the states of which maintain few if any barriers to trade or mobility of the factors of production between themselves. The absence of barriers would quickly become tacit norms, since contravention of them by any one government would lead to punishment-the flight of capital or labor to more hospitable parts of the zone, the mobilization of powerful domestic forces and transnational interests against that government, and the attendant loss of economic well-being for the society as a whole. The norms are tacit but well known; their contravention will be punished, and governments know it; but the enforcement mechanisms work

48. Richard Rosecrance, The Rise of the Trading State (New York: Basic Books, 1986), p. 24.

49. Moravcsik, "Liberalism and International Relations Theory," pp. 26-27. 
without centralized authority, and work outside of the control of any state.

In the industrial West, at least, we know that legal norms are crucial to liberalism. Markets, as Waltz fails to acknowledge, "are probably the social institutions which are most dependent upon normative underpinnings",, 50 it is indeed impossible to imagine markets absent a highly refined, legally-constituted social interest, in the form of civil and property rights, contract and tort law, and mechanisms of formal adjudication by courts. Within a zone of liberalism, these normative underpinnings also facilitate transnational ties and economic interdependence. In fact, although empirical research is sparse, higher levels of international economic transactions among liberal states have expanded the role of national law and courts as regulators of "transnational law." To the extent that this occurs, we can speak of a "zone of law," a zone that substitutes for the illiberal "zone of politics" (wherein either the "political" branches and or the international law of strict state sovereignty control outcomes). ${ }^{51}$

A supranational system based on reciprocal guarantees of property rights, contracts, and adjudication, within a relatively common inter-subjective understanding and respect for the rule of law, is a legal regime of a kind. In it, courts may develop meaningful autonomy from national governments in regulating what is, in effect, transnational society. Lacking coherent metanorms, that society cannot be considered a constitutional regime.

\section{NeOLiberal InStitutionalism}

Relatively less needs to be said about liberal institutionalism (simply a neoliberal theory of regimes) because liberals accept the main tenets of Keohane's MSR. Regimes, they agree, function to resolve collective action problems to the extent that they lower information and bargaining costs. Liberals sometimes recognize, explicitly, that the notion of a regime breaks down the distinction between national and international society. Consider Rosecrance's definition:

50. Kratochwil, Rules, Norms, and Decisions, p. 47.

51. Anne Marie Burley, "Law Among Liberal States: Liberal Internationalism and the Act of State Doctrine," Columbia Law Review 92 (1992): 1909-96. 
A regime exists in a given realm, when countries agree to give up independent decision-making power..... and to constrain their behavior according to certain established norms. A domestic society is a clear example of a regime. Individuals in it give up certain forms of independent behavior .... and in return receive equal treatment and protection of ... [the] laws.

In international regimes, as well, there are obligations placed upon national behavior, and there are sanctions if countries violate their obligations, such as an inability to raise loans in international credit markets. ${ }^{52}$

Somewhat bizarrely, if understandable given the dominance of neorealist perspectives, little or no systematic research exist on the question of the relative autonomy of international institutions. The more relative autonomy any regime possesses, the closer we are to modern forms of type 2 and 3 constitutionalism. Such autonomy is more likely to develop within a zone of liberalism than outside such a zone, and I can offer three arguments as to why this should be so. First, a regime embedded within a zone of liberalism is not as likely to be turned into a forum for interstate conflict about first principles. The kind of geopolitical or ideological struggle that has afflicted the various organs of the U.N. regime, including the role played by international law and the International Court of Justice, ${ }^{53}$ will be absent. Thus states will be less likely to be as vigilant about protecting prerogatives of sovereignty traditionally understood. Second, any stable liberal regime is likely to produce a set of domestic actors and transnational coalitions, possessed of concrete interests, favoring maintenance or expansion of the regime. Because liberal regimes, like liberal states, are embedded in transnational society, private actors and groups may very well go directly to formal institutions created by the regime to get what they want, bypassing state governments when they do not get what they want. This is in part the logic of Haas's "neofunctionalism," an early strain of neoliberal institutionalism. ${ }^{54}$

52. Rosecrance, Rise of the Trading State, p. 59.

53. Thus the United States justified pulling out of the Nicaragua $v$. U.S. case before the International Court of Justice (1984-86), among other things, because Nicaragua was an illiberal state and the ICJ included a judge from the Soviet Union. 1958).

54. Ernst B Haas, The Uniting of Europe (Stanford: Stanford University Press, 
Finally, liberal regimes are more likely to produce not only constraining rules but "enabling rules," rules that "set actors free to pursue their own goals. ${ }^{\prime \prime 5}$ To the extent that normative structures are not purely negative, that they actually constitute social interaction, a regime may be the source of a kind of normative vocabulary which comes to penetrate and even overwhelm the normal, interest-driven language of politics. Because norms enable social actors "to act, to communicate intentions, to criticize claims, and justify choices," norm-based social interaction and the "concomitant process of interstitial lawmaking" may be crucial to what we mean by supranational constitutionalism. ${ }^{56}$ Thus, a liberal regime, like a constitution, may create, reinforce, and disseminate the social interest, while delegitimizing narrow self-interest.

\section{Multilateralism}

Multilateralism incorporates the insights of liberal institutionalism, but goes further. Ruggie defines multilateralism as:

an institutional form that coordinates relations among three or more states on the basis of generalized principles of conduct: that is, principles which specify appropriate conduct for a class of actions, without regard to the particularistic interests of the parties or the strategic exigencies that may exist in any specific occurrence. ${ }^{157}$

Broken down further and translated into the language of this article, multilateral forms are a subset of liberal regimes, distinguishable not in kind but by the highly demanding extent to which metanorms, tacit or explicit, cohere and are perceived as immutable.

In multilateralism, writes Caporaso, three properties are fused. ${ }^{58}$ The first is that states party to a multilateral relationship will be governed by "general principles," principles that are in

55. Kratochwil, Rules, Norms, and Decisions, p. 61.

56. Ibid., p. 61.

57. John G. Ruggie, "Multilateralism: The Anatomy of an Institution," in Multilateralism Matters, ed. J. Ruggie (New York: Columbia University Press, 1993), p. 11.

58. James A. Caporaso, "International Relations Theory and Multilateralism: The Search for Foundations," in Multilateralism Matters, pp. 51-90. 
fact legal, in fact codified in international and transnational law. The property is a metanorm, and from a normative point of view, a multilateral regime shades toward a supranational rule of law community. The second property is "indivisibility": that states party to a multilateral arrangement have agreed to resolve certain collective action problems together on an ongoing basis. This is an explicitly integrative metanorm; a multilateral regime constitutes a true collective venture, as when states create free trade areas and customs unions (EU) or come to define an attack against any one state as an attack against all (NATO). The third property is an underlying "diffuse reciprocity," the expectation that iteration of the game will tend to leave no player a net loser over the long run. As Caporaso puts it, diffuse reciprocity "adjusts the utilitarian lens for the long view, emphasizing that actors expect to benefit in the long run and over many issues rather than on every issue." 59 Diffuse reciprocity, which is probably a function of other unspecified metanorms, serves to reinforce the social legitimacy of the community.

Multilateralism-like constitutionalized regimes generallyrequires us to reconceptualize how (and whether) we ought to distinguish between domestic and international society. In neorealist approaches, state sovereignty is understood to be unified and indivisible. From a neoliberal standpoint, the notion of sovereignty is inherently problematic, because state capacities and the "national interest" do not cohere, over time and across issue areas except in an excessively formal sense. In a highly developed multilateral setting, sovereignty may be little more than "a bundle of discrete [public] functions, or competences." 60 These competences are detachable; they can be pulled away from the national bundle and woven into a supranational bundle. At that point, within that sector, we can no longer speak of state sovereignty. From a normative perspective, it no longer exists. At the same time, the existence of multilateral metanorms raises the question of exactly how, within the sector or sectors concerned, a multilateral organization differs from a state.

59. Ibid., p. 54.

60. Alec Stone, "Ratifying Maastricht: France Debates European Union," French Politics and Society 11 (1993): 70-88. 


\section{NEOLIBERALISM AND THE EU}

Neoliberals must reject the structural realist view that the reemergence of multipolarity will in itself reverse incentives to cooperate. First, the "game" being played in the liberal world is not one being played by coherent states who must of necessity be more concerned with relative gains than absolute ones. Second, for neoliberals, like proponents of MSR, the existence of organizations at the supranational level can matter a great deal to how states come to define and express their interests. The MSR theory of regimes, however, does not allow institutions substantial autonomy. States, and especially strong states, remain the fundamental unit of analysis; but they interact in a formally constituted forum-the regime. In MSR, regimes function as intervening not independent variables. ${ }^{61}$ A strain of neoliberal (and multilateral) institutionalism specifically designed to explain European integration, neofunctionalism and its variants, suggests however that once well-defined functional goals are transferred from the national to the supranational level, formal supranational institutions can exercise a great deal of autonomy in service of the social interest broadly conceived.

Applied to concrete cases, theoretical differences can yield huge analytical consequences. European integration, for example, accelerated in the 1980s. A MSR analysis, like that of Moravcsik, argued that this process (and the history of European integration generally) was constrained by state-to-state bargaining over relative gains; the outcome, in this case the Single European Act (1986), was in consequence a minimalist, lowest commondenominator outcome. ${ }^{62}$ Neoliberals, in contrast, argued that stateto-state bargaining was only a part of a bigger picture, and that the EU Commission, ${ }^{63}$ in conjunction with powerful (private) transnational actors, were crucial to the Single Act's success. ${ }^{64}$ As important, the Single Act, far from freezing the lowest common

61. Krasner, "Structural Causes and Regime Consequences," pp. 100-101.

62. Andrew Moravcsik, "Negotiating the Single European Act," in The New European Community, ed. Keohane and Hoffmann, pp. 41-84.

63. The Commission, the executive agency of the EC, is formally autonomous from the member states.

64. Wayne Sandholtz and John Zysman, "1992: Recasting the European Bargain," World Politics 42 (1989): 95-128. 
denominator, actually produced a dynamic process of supranational constitution-building that ultimately culminated in the Treaty on European Union (1992). ${ }^{65}$ Finally, some neoliberals, while generally agreeing that American hegemony provided the necessary conditions for the initial institutionalization of pan-European and transatlantic liberalism, argue that multilateralism itself forms a powerful substructure within systemic anarchy. Focusing exclusively on security arrangements, Morgan has argued that multilateralism may be more than enough to offset the destabilization of the region caused by the retreat of the Soviet Union from Central Europe. ${ }^{66}$

\section{SUMMARY}

Theories of international politics can be distinguished, among other things, by how they account for order within anarchy. Order is a generic term for any given solution to a given collective action problem. In the world depicted by neorealism, order is produced and operates systemically. This order is not fundamentally an order built of norms; norms that do exist reflect, and are produced by, the distribution of power. Regimes are a formalization of those norms that permit states to overcome collective action problems in anarchy. Order in a regime-governed world, operates sectorally, or functionally. Regime theory, however, read without differentiating between neorealist and neoliberal variants lacks clarity. As I have tried to argue here, regimes embedded in liberal international society will be qualitatively different than those maintained outside the zone of liberalism. Last, multilateralism is the most demanding of institutional forms of cooperation and, not coincidentally, is perhaps unimaginable outside of a zone of liberalism. Multilateral order is produced and operates according to metanorms favoring or establishing the formation of legallyconstituted and governed communities of states. When we break multilateralism down into its constituent metanorms, it is easy to see that multilateralism, not wholly unlike liberal

65. Wayne Sandholtz, "Choosing Union: Monetary Politics and Maastricht," International Organization 47 (1993): 1-39.

66. Patrick Morgan, "Multilateralism and Security: Prospects in Europe," in Multilateralism Matters, pp. 327-64. 
constitutionalism, comes to constitute a kind of metanorm in and of itself.

\section{Norms and Supranationalism}

Anarchy does not imply disorder, but only the absence of centralized government. Can order within anarchy ever be constitutional order? The answer to this question depends a great deal on how we think about anarchy. The autonomy of international relations as a field partly rests on the claim that the very structure of domestic politics (hierarchy) is qualitatively different than that of international politics (anarchy). At the same time, the regime literature shows that anarchy is a highly elastic structure, that it can accommodate a great deal of decentralized government.

The strongest argument I can make for supranational constitutionalism begins with rejecting the fundamental distinction between domestic and international society. The normative perspective developed here is one way to do so. Some restatement and clarification is in order. First, we err or fool ourselves by taking for granted law and constitutions. After all, the development of constitutionalism is inherently problematic in any social setting. Instead of deriving our understanding of constitutionalism with reference to a handful of long-lived, thriving examples, it would be better to ask: how do preconstitutional normative orders function?; and why is the development of stable constitutionalism so elusive everywhere, in every context?

Second, domestic constitutional orders are not all alike. Recall that in my crude typology in part 1, type 1 metanorms are virtually devoid of autonomy, that is, they reflect rather than redirect or reshape underlying power relationships; type 2 and 3 constitutions legitimize public power by way of popular consent; and type 3 constitutions tightly regulate the content of legal norms. In the real world, stable type 2 or type 3 constitutions are rare; in most states, just as in the neorealist's account of world politics, power imposes its own "metanorms." Further, the supposed contrast between "law and order" domestic society and "anarchic" international society is a caricature. Outside of a few dozen states, rule of law ideology is not firmly rooted in domestic society, and laws are often violated, left unenforced, or bent into strange shapes 
when they are. In contrast, within liberal international regimes compliance with and consistent enforcement of transnational and international law may be extremely high. In a zone of liberalism, transnational and international law may have relatively more status, autonomy, and legitimacy than legal norms in many domestic settings. Equally unrealistic is the notion that legal norms make up a formal, coherent system in domestic but not international society. In domestic society, too, legal norms are produced, applied, and interpreted in a world of politics. Lawthe social interest-is always being contested among social actors (and in fact this all the more true where constitutionalism is most firmly rooted).

Last, and most important for my purposes, the following sequence appears to be equally applicable to both international and domestic society: norms facilitate cooperation; norm-based cooperation can be institutionalized, in the form of regimes; a basic function of regimes is to generate legal norms binding equally on all parties; these legal norms are produced according to codified metanorms; and some regimes are inseparable from what are in effect organic metanorms. If, in international society, we can reach this last stage in the sequence, then we are in the presence of a full-blown supranational constitution. The notion of "a constitution" can travel beyond the nation-state.

\section{Conclusion: A Regime Continuum}

Figure 1 (see next page) is a continuum capable of situating all forms of institutionalized cooperation, from the most primitive to the supranational constitutional. It also represents schematically the argument presented here. The continuum captures two dimensions. The first is the relative status of regime norms. The further right any regime may be positioned on the continuum, the more formal are the norms constituting the regime. At the far left, we find tacit norms and unspoken rules; at the far right, we find legal and metanorms. The second dimension captured is the relative degree of institutionalization. The further right any regime may be positioned on the continuum, the greater the institutionalization of the social interest. At the far left, we find the social interest expressed only in the persistence of the normbased behavior itself; on the far right we find the social interest 


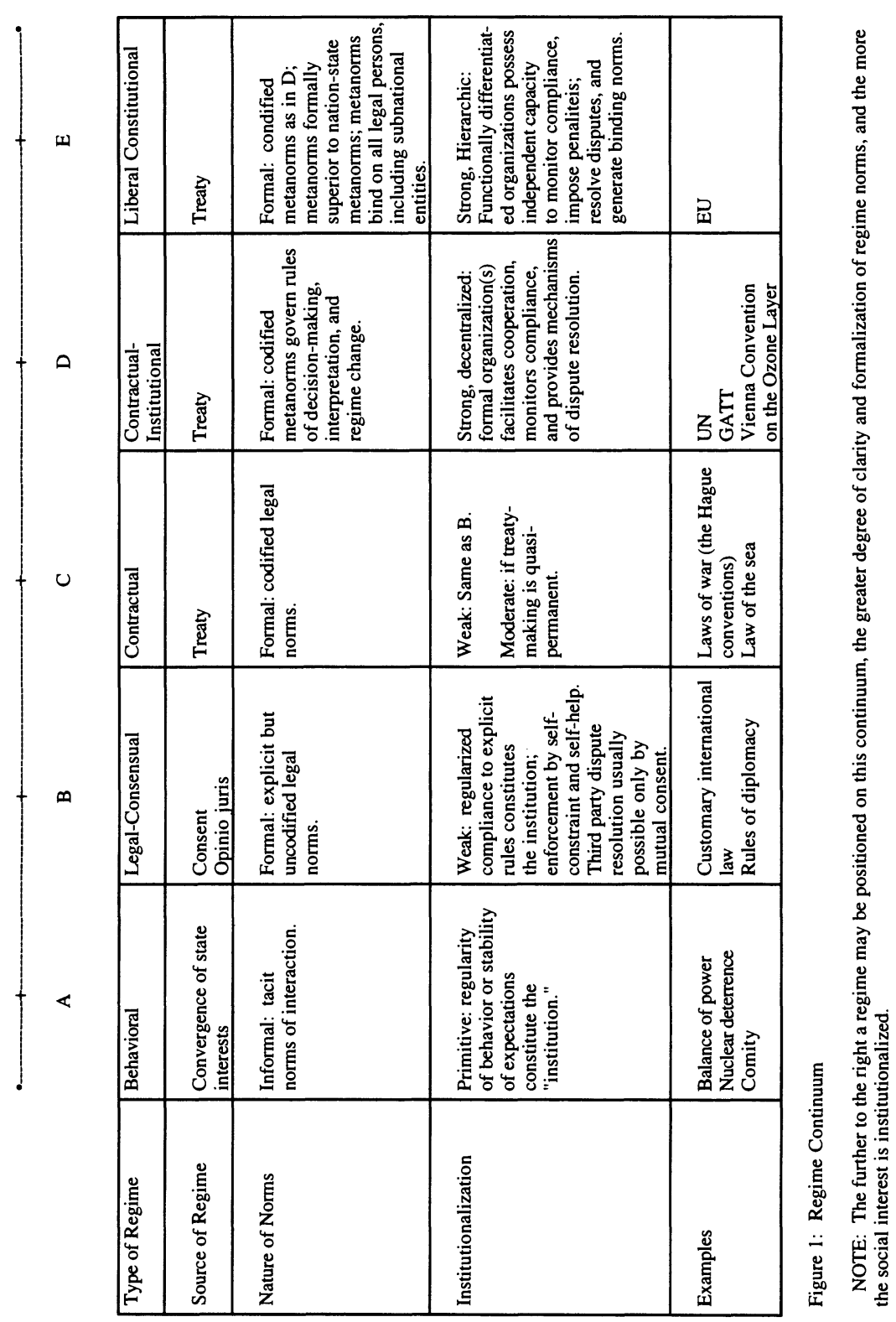


identified explicitly with formal organizations possessed of autonomous capacity. I will take each regime type in turn, from left to right, A-E.

A type A regime is a normative structure without express legal status. It is instead behavioral, that is, the regime results from social interaction, or more precisely a convergence of state interests stable enough to have posed a collective action problem. The solution to that problem-norms-is a tacit one. The regime exists to the extent that the states involved come to have stable expectations about the consequences of particular actions. Institutionalization is primitive. As Kratochwil has it, "the most basic form of [normative] institutionalization" occurs when "A's expectation of B will include an estimation of B's expectations of $A .{ }^{\prime 67}$ The norms of deterrence, as well as what international lawyers call comity (norm-guided courtesy among states), are type A regimes.

Type $B$ and $C$ regimes are familiar as the basic stuff of traditional international law. Type $B$ regimes flow from customary international law. A preexisting norm "ripens" into a right or duty of customary law when virtually all states believe that the norm is possessed of legal status (opinio juris). Unanimous consent is a demanding standard, accounting for both the relatively high legitimacy of customary international law and its minimalist, lowest common denominator content. Type $C$ regimes flow from contractual instruments: the rights and obligations of the states party to the regime are codified by treaty law. Only the most primitive enforcement mechanisms exist. The first mechanism is self-restraint, the extent to which states have an interest in avoiding a reputation as an "outlaw" state. States may know or expect that defection will be punished by exclusion from future cooperative ventures. The second mechanism is self-help. Customary international law allows for states to punish violators of international law as long as that punishment is proportional to the injury suffered as a result of the violation. These decentralized enforcement mechanisms are what most political scientists notice if they notice international law at all. 
What type A, B, and C regimes lack, compared with type D and $E$ regimes, are metanorms and formally constituted, relatively autonomous organizations. Type D and E regimes are constitutional regimes: codified metanorms govern how legal norms are produced, applied and interpreted. Institutionalization takes the form of concrete organizations formally autonomous from the parties to the regime. The function of these organizations is to represent the social interest. Type $D$ regimes are the regimes of MSR and liberal institutionalism: minimally, such regimes lower information and bargaining costs; maximally, they independently monitor compliance to lower-order norms, provide third party dispute resolution, and levy penalties for noncompliance.

Based on my analysis of neoliberalism in part II, the more any regime is constituted by non-liberal states, the more it will be positioned to the left of the continuum relative to liberal regimes. Likewise, liberal-institutional regimes governed by the metanorms of multilateralism, will shade-actually they will lurch-to the right. Type E regimes are a form of supranational-type 3 constitutionalism. In them, metanorms govern not only how legal norms are produced but constrain their content on both the supranational and national levels. As far as I am aware, the EU is the first example of such a regime in world history.

The EU is in fact an extraordinarily intricate example of a supranational constitution. The features of this constitutionalism are well known. ${ }^{68}$ First, national competence to make policy in a wide range of functional areas has been entirely preempted by supranational competence. In such areas, "member states are not only precluded from enacting legislation contradictory to Community law but they are preempted from taking any action at all." ${ }^{\prime 69}$ Second, the treaties, as a matter of Community law, are normatively superior to national metanorms and national lowerorder norms. That is, EU metanorms trump national metanorms. Third, provisions of the treaty bestow onto all legal persons, including private citizens, rights which can be enforced not only by the European Court of Justice, but also by national courts. These

68. See note 2.

69. Joseph Weiler, "The Community System: The Dual Character of Supranationalism," Yearbook of European Law 1 (1981): 277. 
rights claims can even be used to set aside national legal norms in the service of protecting the superiority of the Community's metanorms. Thus, there is a form of judicial review based on the treaties, which are conceived as constitutional (metanorms). The $\mathrm{EU}$ is a case of supranational constitutionalism that appears to be theoretically indistinguishable from constitutional federalism..$^{70}$

If all of this is so, the distinction between international regimes and domestic constitutional forms is relative not absolute. The next step will be to move from the abstract analysis presented here, to a more systematic comparison of a range of constitutional regime forms. In doing so, we might demonstrate just how and why constitutionalization makes a difference.

70. Lenaerts, “Constitutionalism and the Many Faces of Federalism," pp. 20564. 
http://www.jstor.org

\title{
LINKED CITATIONS
}

- Page 1 of 2 -

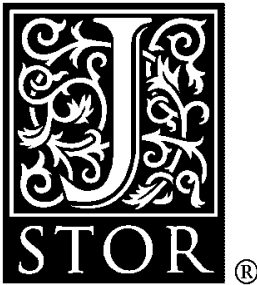

You have printed the following article:

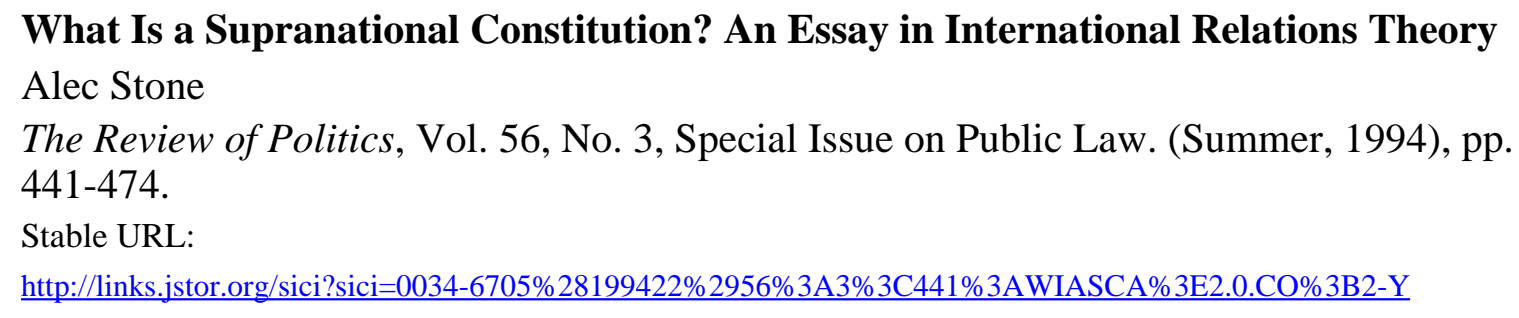

This article references the following linked citations. If you are trying to access articles from an off-campus location, you may be required to first logon via your library web site to access JSTOR. Please visit your library's website or contact a librarian to learn about options for remote access to JSTOR.

\section{[Footnotes]}

\author{
${ }^{2}$ Lawyers, Judges, and the Making of a Transnational Constitution \\ Eric Stein \\ The American Journal of International Law, Vol. 75, No. 1. (Jan., 1981), pp. 1-27. \\ Stable URL: \\ http://links.jstor.org/sici?sici=0002-9300\%28198101\%2975\%3A1\%3C1\%3ALJATMO\%3E2.0.CO\%3B2-O
}

\section{${ }^{2}$ The Transformation of Europe}

J. H. H. Weiler

The Yale Law Journal, Vol. 100, No. 8, Symposium: International Law. (Jun., 1991), pp. 2403-2483.

Stable URL:

http://links.jstor.org/sici?sici=0044-0094\%28199106\%29100\%3A8\%3C2403\%3ATTOE\%3E2.0.CO\%3B2-V

\author{
${ }^{3}$ An Evolutionary Approach to Norms \\ Robert Axelrod \\ The American Political Science Review, Vol. 80, No. 4. (Dec., 1986), pp. 1095-1111. \\ Stable URL: \\ http://links.jstor.org/sici?sici=0003-0554\%28198612\%2980\%3A4\%3C1095\%3AAEATN\%3E2.0.CO\%3B2-4
}

NOTE: The reference numbering from the original has been maintained in this citation list. 
http://www.jstor.org

\title{
LINKED CITATIONS \\ - Page 2 of 2 -
}

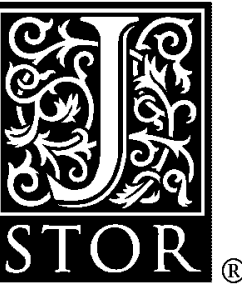

\footnotetext{
${ }^{8}$ Constitutionalism and the Many Faces of Federalism

Koen Lenaerts

The American Journal of Comparative Law, Vol. 38, No. 2. (Spring, 1990), pp. 205-263.

Stable URL:

http://links.jstor.org/sici?sici=0002-919X\%28199021\%2938\%3A2\%3C205\%3ACATMFO\%3E2.0.CO\%3B2-D
}

\section{${ }^{10}$ Theories of International Regimes}

Stephan Haggard; Beth A. Simmons

International Organization, Vol. 41, No. 3. (Summer, 1987), pp. 491-517.

Stable URL:

http://links.jstor.org/sici?sici=0020-8183\%28198722\%2941\%3A3\%3C491\%3ATOIR\%3E2.0.CO\%3B2-W

\section{${ }^{24}$ Anarchy and the Limits of Cooperation: A Realist Critique of the Newest Liberal Institutionalism}

Joseph M. Grieco

International Organization, Vol. 42, No. 3. (Summer, 1988), pp. 485-507.

Stable URL:

http://links.jstor.org/sici?sici=0020-8183\%28198822\%2942\%3A3\%3C485\%3AAATLOC\%3E2.0.CO\%3B2-Z

\author{
${ }^{32}$ The Limits of Hegemonic Stability Theory \\ Duncan Snidal \\ International Organization, Vol. 39, No. 4. (Autumn, 1985), pp. 579-614. \\ Stable URL: \\ http://links.jstor.org/sici?sici=0020-8183\%28198523\%2939\%3A4\%3C579\%3ATLOHST\%3E2.0.CO\%3B2-I
}

\section{${ }^{51}$ Law among Liberal States: Liberal Internationalism and the Act of State Doctrine} Anne-Marie Burley

Columbia Law Review, Vol. 92, No. 8. (Dec., 1992), pp. 1907-1996.

Stable URL:

http://links.jstor.org/sici?sici=0010-1958\%28199212\%2992\%3A8\%3C1907\%3ALALSLI\%3E2.0.CO\%3B2-2

\section{${ }^{65}$ Choosing Union: Monetary Politics and Maastricht}

Wayne Sandholtz

International Organization, Vol. 47, No. 1. (Winter, 1993), pp. 1-39.

Stable URL:

http://links.jstor.org/sici?sici=0020-8183\%28199324\%2947\%3A1\%3C1\%3ACUMPAM\%3E2.0.CO\%3B2-Q

NOTE: The reference numbering from the original has been maintained in this citation list. 